\title{
A participação do público no telejornalismo local: análise de conteúdo do quadro "VC' no MG"
}

\author{
Public participation in local television news: content analysis of the "VC \\ no $M G^{\prime \prime}$
}

2 Aline da Fonseca Pinna aline.pinna@yahoo.com.br

1 O nome original do quadro possui abreviatura. O "VC" equivale ao pronome de tratamento "Você".

2 Mestra em Comunicação e Sociedade pelo PPGCOM/UFJF

\section{Resumo}

Os meios de comunicação, de forma geral, tiveram que se ajustar (interna e externamente) conforme os surgimentos de novas tecnologias. Esta pesquisa busca analisar o quadro "VC no MG", que é transmitido na $1^{\text {a }}$ Edição do MG1, da TV Integração, afiliada da Rede Globo. $O$ programa utiliza esse quadro para inserir a participação dos telespectadores na grade da programação. Para isso, a produção do telejornal usa recursos, como aplicativos e redes sociais, para obter informações sobre assuntos da região, onde a emissora atua, se estabelecendo como estratégia do canal e também como novas possibilidades de participação para o público. 0 projeto tem como objetivos apresentar o jornalismo participativo no "VC no MG", verificar como os conteúdos são aproveitados pela equipe do telejornal e como o telespectador é inserido nas edições. Para isso, foram analisadas três edições do mês de abril de 2018, de forma a mostrar a narrativa jornalística e suas estratégias para conduzir o programa e, assim, informar o telespectador. A metodologia utilizada é baseada nas categorias propostas por Bardin (2009) sobre distintas etapas de Análise de Conteúdo e, como resultado, obtivemos uma considerável interatividade do canal com o telespectador, gerando uma maior proximidade entre eles, sendo esta uma das consequências da convergência das mídias.

\section{Palavras-chave:}

Jornalismo participativo. MG1. Telejornalismo. VC no MG.

\begin{abstract}
The means of communication, in general, had to adjust (internally and externally) according to the emergence of new technologies. This research seeks to analyze the program "VC no MG", which is broadcasted in the 1st Edition of MG1, by TV Integração, an affiliate of Rede Globo. The program uses this framework to insert the participation of viewers in the programming schedule. For this, the newscast production uses resources, such as applications and social networks, to obtain information on issues in the region, where the station operates, establishing itself as a channel strategy and also as new possibilities for the public to participate. The project aims to present participatory journalism in "VC no $M G$ ", verifying how the contents are used by the TV news team and how the viewer is included in the editions. For this, three editions of April 2018 were analyzed, in order to show the journalistic narrative and its strategies to conduct the program and, thus, inform the viewer. The methodology used is based on the categories proposed by Bardin (2009) on different stages of Content Analysis and, as a result, we obtained considerable interactivity between the channel and the viewer, generating greater proximity between them, which is one of the consequences of the convergence of the media.
\end{abstract}

\section{Keywords:}

Participatory journalism. MG1. Telejournalism. VC no MG.

Como você deve citar?

PINNA, Aline da Fonseca. A participação do público no telejornalismo local: análise de conteúdo do quadro "VC no MG". Cadernos UniFOA, Volta Redonda (RJ), v. 16, n. 46, p. 1-13, ago, 2021 


\section{INTRODUÇÃO}

Os veículos tradicionais tiveram que se adaptar às novas ferramentas disponíveis graças às plataformas e aplicativos digitais. Nesse âmbito, o telejornalismo construiu técnicas e narrativas, permitindo assim o desenvolvimento do jornalismo em geral. É o efeito da convergência midiática. A mídia se deparou com o aumento de possibilidades de participação do público com os meios, tendo um novo receptor. 0 espectador tornou-se mais exigente e ativo perante as informações transmitidas.

Carlos Camponez (2002) aborda sobre três aspectos de proximidade: geográfica, social e psicoafetiva. $\mathrm{O}$ autor trata essa proximidade, ambientada localmente, em um espaço e tempo territorialmente identificados. Essas questões podem ser situadas no jornalismo, especialmente, no âmbito regional, pois acarreta em uma partilha de valores e de um determinado território. Logo, são geradores de modos comunicacionais, aspectos de que a imprensa local é um exemplo.

Ainda segundo Camponez (2002), compete aos veículos de comunicação, um vínculo de proximidade entre as pessoas, a cultura e as tradições em que o meio informacional é produzido, além de abarcar os sentidos em que a comunidade está introduzida. Dessa forma, o canal televisivo é considerado um ambiente identificável, sendo o local onde os acontecimentos são noticiados e compartilhados. É como se fosse um espaço familiar, no qual há elos de cumplicidade.

Esse companheirismo argumentado provoca um empenho de ambas as partes envolvidas: o meio de informação e o público. É fundamental que os veículos de comunicação se dediquem a conquistar e manter esse elo de proximidade entre o povo, a cultura e os costumes, isto é, é a oferta de conteúdos da emissora e o contato direto com a população sobre os assuntos e problemas que os afetem diretamente. Assim, as notícias jornalísticas passaram a receber as opiniões dos cidadãos, ou seja, o público está abastecendo o jornalismo com conteúdos colhidos por eles mesmos, captados por aparelhos celulares, por exemplo.

Diante desse contexto, este artigo visa apresentar o jornalismo colaborativo sobre o quadro "VC no $\mathrm{MG}^{\prime 3}$, em três edições do mês de abril de 2018 (dias 04, 05 e 26). Essa seleção deu-se por ser um período em que se discorreram diferentes problemas (buracos em rua, ponte em estado instável e lote negligenciado e sem manutenção). 0 trabalho ainda verificou como os materiais são aproveitados pela produção do programa em sua programação e, consequentemente, mostrou como é feita a inserção do público no decorrer das edições.

Para o avanço deste estudo, foram usados fundamentos e conceitos sobre o surgimento da TV no país, o entendimento de telejornalismo e a sua relação com a inserção das novas tecnologias comunicacionais e aparelhos digitais. Foram escolhidos autores como Primo (2003), Mattos (2004) e Bardin (2009) para fundamentar essas e outras questões. Escolheu-se esses autores devido aos seus estudos aprofundados sobre os assuntos que foram aqui tratados. Também, foi apresentada a análise do quadro do MG1, juntamente com as suas observações.

Dado o exposto, acredita-se que o trabalho é de grande importância para o atual cenário (tele) jornalístico, principalmente, para o aspecto glocal. Além disso, é relevante mostrar que os profissionais de comunicação devem estar atualizados e inseridos em diversas plataformas digitais, com o intuito de aproximar-se, cada vez mais, da sociedade. Logo, como exemplo de proximidade da emissora local

3 O quadro faz parte do programa telejornalístico MG1, da TV Integração, da Rede Globo. A afiliada cobre a Zona da Mata mineira e Campo das Vertentes. 
com o seu público, tem-se a introdução de alguns telespectadores (seja por imagens, vídeos ou áudios) no decorrer das edições do programa.

\section{SURGIMENTO DA TELEVISÃO ENTRE OS BRASILEIROS}

Os relatos e biografias nos fazem descobrir de onde viemos e qual o melhor caminho a seguir. 0 percurso nos fornece a construção da identidade, das regras e dos valores. É a partir daí que podemos definir uma representação histórica fundamental para a identidade social, sendo uma delas a narração da televisão, por exemplo.

Célia Mota (2013) argumenta que a televisão transforma a identidade social a partir dos textos e/ou narrativas de um programa de TV, pois eles reforçam a construção de maneira social. A autora explica que o televisor pode trazer importantes aspectos. "Uma característica essencial da televisão é, pois, a polissemia ou a multiplicidade de significados. Para esse efeito concorrem os textos televisivos, feitos de falas, imagens, gráficos, artes, no que se convencionou chamar de texto multimodal" (MOTA, 2013 , p. 50). Logo, as identidades culturais e sociais são afetadas por conta dessas transformações televisivas e audiovisuais.

A inserção de novos aparelhos possibilitou o desenvolvimento tecnológico, narrativo e, também, o de capacitação das pessoas ligadas a essa área, pois havia a necessidade de profissionais que pudessem lidar com os novos modelos e formatos. Percebemos que o televisor ganhou novas adaptações e ainda continua sendo um veículo de grande reconhecimento mundial, pois tornou-se um aliado que possibilita a expansão dos aspectos de interação com as pessoas, ou seja, "é um meio de comunicação massivo, popular e de fácil acesso, configurando-se como uma das principais fontes de informação, entretenimento, educação e prestação de serviços" (SILVA; EMÉRITO, 2014, p. 2). É a TV que direciona a vivência do indivíduo, levando para "dentro de casa" as informações necessárias para a atualização e aprendizado do ser humano.

Desse modo, notamos que a TV já havia se firmado no Brasil como o meio de comunicação mais ativo no setor da indústria cultural. Assim, "nesses mais de sessenta anos de presença da televisão em nosso país, muita coisa mudou - formatos televisuais, tecnologia, linguagem" (CONTATO, 2015, p. 2), isto é, o televisor passou por diversos modelos, estéticas e narrativas.

Mesmo com a ampliação de veículos comunicacionais, a televisão ainda continua sendo o meio de informação preferido entre os brasileiros. Vemos isso na divulgação da Pesquisa Brasileira de Mídia $2016^{4}$, que mostra que $63 \%$ dos brasileiros se informam mais sobre os acontecimentos por meio da TV. Em segundo lugar, aparece a Internet com $26 \%$; o rádio está em terceiro com $7 \%$; o jornal com $3 \%$ e, por último, com 1\%, aparecem outros meios.

\section{TELEJORNALISMO E A PRESENÇA DO TELESPECTADOR}

Em meio ao aparecimento de novas tecnologias de informação e comunicação, podemos perceber novos relacionamentos entre a mídia e a audiência. Isso se deu através da Web 2.0, onde variadas plataformas foram criadas e passaram a fazer parte do dia a dia dos internautas. Essa nova geração passou a ter uma interação mais forte do que as gerações anteriores, já que a Internet é um ambiente

4 Disponível em: http://pesquisademidia.gov.br/\#/Geral/details-917. Acesso em: 05 ago. 2018. 
em que os usuários podem expressar suas ideologias, compartilhar documentos (arquivos, fotografias, vídeos) e/ou participar de fóruns, enquetes sobre qualquer assunto. (JENKINS; GREEN; FORD, 2015)

Nilo (2009) cita o teórico francês Wolton (1996), quando constitui a televisão a um laço social. Os canais de comunicação funcionam como laços que unem os seres humanos, pois possibilita mais interação entre os indivíduos, seja por textos ou por imagens e vídeos. É como se fosse um tipo de laço invisível, pois ao mesmo tempo em que uma pessoa assiste à TV, sabe-se que outro indivíduo também assiste. Torna-se uma reponsabilidade global juntamente com uma realidade sociocultural da sociedade.

Nos principais telejornais do Brasil pode-se encontrar interatividade e informações diárias sobre os principais acontecimentos do país e do mundo. Então, o noticiário pode ser compreendido como o lugar "que reúne uma seleção de notícias que recebem tratamento discursivo transformando-se em reportagens curtas e objetivas que, organizadas em blocos e por temas, exibe-se com horário, cenário e apresentadores fixos na televisão" (EMERIM; BRASIL, 2013, p. 6-7). Esse conjunto de fatores compõem os telejornais brasileiros.

Já os noticiários locais relatam, principalmente, as notícias da região coberta pela emissora. Eles buscam dar mais atenção à comunidade local, acarretando em uma maior aproximação com as necessidades dos moradores. Logo,

\begin{abstract}
[...] não podemos deixar de reconhecer o importante papel dos telejornais como fonte de informação e conhecimento na sociedade brasileira. Em um país onde a cultura oral é expressiva - a despeito da importância da tradição literária para algumas parcelas da população, ainda que restritas -, e cerca de $10 \%$ da população é analfabeta enquanto outros 30 milhões são analfabetos funcionais, noticiários de TV se estabelecem como um lugar de referência. (SCHLAUCHER, 2012, p. 5)
\end{abstract}

Nota-se a importância que o telejornal tem para os brasileiros, pois, somente em um período de tempo, as notícias vão sendo veiculadas para milhares de telespectadores com as suas determinadas interpretações de realidade. A identidade social é construída, porque "os telejornais, junto com outras instituições, atuam na construção social da realidade e têm como uma de suas principais preocupações a orientação de homens e mulheres no cotidiano" (SCHLAUCHER, 2012, p. 5). Logo, o noticiário é um programa imprescindível para a formação da identificação do cidadão.

Com o passar dos anos, o jornalismo passou por mudanças em muitos aspectos, como o de distribuição, circulação, produção e consumo. A inserção de plataformas e dispositivos digitais fez com que os setores comunicacionais fossem modificados, possibilitando que telejornal não escapasse de um novo olhar. A interação com múltiplas redes ganhou espaço no jornalismo e, dessa maneira, a intensa participação do público se destacou nas telas da televisão e na "segunda tela".

Finger e Canatta (2012) explicam que a "segunda tela" transpassa os limites do ambiente doméstico, se estendendo pelas ruas e gerando uma experiência mais complexa e atrativa. Dessa forma, os programas passaram a ser exibidos em todo lugar. Piccinin (2016) registra sobre esse processo interativo, citando o noticiário, já que

[...] no caso o telejornal, é a prova desta complexificação contínua que exige também novos olhares para as dinâmicas interativas entre emissor e receptor que acaba por mudar também o próprio processo produtivo do que temos convencionalmente nomeado como telejornal. (PICCININ, 2016, p. 12)

Dado o exposto, o telejornalismo passa por significativas mudanças nos seus formatos, produções e discursos com a intenção de chamar a atenção das pessoas. Para isso, tem-se como apoio as novas tecnologias e os sistemas de comunicação mútuos. É imprescindível que os profissionais de comunicação passem a aderir a esse novo contexto social, já que as pessoas estão migrando para novas plataformas. 
Segundo Lima (2014), a forma de ver televisão, incluindo o telejornal, mudou muito. 0 jornalismo pós-moderno se baseia naquela informação instantânea que é debatida, compartilhada, comentada e criticada. As redes sociais e aplicativos são as ferramentas que os usuários utilizam para conversar com os jornalistas, possibilitando novas funções ao comunicador, obrigando, assim, a presença das emissoras nessas plataformas.

Com o fenômeno da convergência, os conteúdos jornalísticos estão cada vez mais dinâmicos e começam a dialogar mais entre si, atravessando - inclusive - diversas plataformas. É cada vez mais comum, por exemplo, a indicação dentro do telejornal - através dos apresentadores ou nas próprias matérias - de conteúdos "externos" relacionados aos assuntos tratados, localizados nas páginas virtuais dos telejornais, em blogs de quadros especiais etc., além da convocação para participação dos telespectadores na construção de novos conteúdos, seja com vídeos ou opiniões/enquetes (que muitas vezes servem de pauta para outras matérias). (LIMA, 2014, p. 5)

Considerando essas características, o telejornal não expõe na sua programação todos os conteúdos recebidos pelos seus seguidores nas redes. Acredita-se que a equipe do programa tem um critério de seleção de temas para a comunidade, ou seja, a produção considera o que é importante para a população para, então, ser transmitido.

Mesmo com essa frequência de participação por meio do dispositivo móvel, Crocomo, Cavenaghi e Frazão (2013) salientam que o público está presente no processo produtivo dos jornais há muitos anos. Nos primeiros anos do surgimento do televisor no país, havia a preocupação de ouvir as propostas e opiniões das pessoas, com o uso do telefone e cartas, por exemplo, que foi fundamental a esse sistema, utilizado como estratégia da produção do programa para a interação, naquele período.

Hoje, o espectador tem maneiras mais sofisticadas para interagir. Os programas passaram a dar mais espaços ao público, por meio de vídeos e fotografias, sejam de denúncias ou de problemas que moradores encontram no bairro, cidade, estado e/ou país. "Cada vez mais o telespectador é convidado a se tornar um aliado na produção da notícia, principalmente em um momento no qual as emissoras reformulam seus modelos de negócio" (CROCOMO; CAVENAGHI; FRAZÃO, 2013, p. 2-3). Desse modo, o espectador tornou-se um produtor de conteúdo.

A narrativa jornalística trouxe um novo ritmo no jornalismo e na sua produção. As técnicas e edições tiveram que ser moldadas, levando-se em conta as possibilidades de participação dos usuários no processo de produção e distribuição de conteúdo. De acordo com Piccinin e Soster (2012), a disseminação da midiatização como um espaço com aparatos tecnológicos, nomeando novas maneiras de vida e com interações caracterizadas por novas estratégias e formas de planejamento e organização, colocaria todos em uma mesma realidade, permitindo o conhecimento e o reconhecimento ao mesmo momento.

As pessoas passaram a estabelecer relações, tomar decisões, organizar e apresentar suas experiências, relatos e histórias, de forma a atribuir sentidos à existência. Contudo, foi escolhido o quadro "VC no MG" por ser uma amostra que apresenta mudanças sofridas no jornalismo de televisão, já que evidencia a frequente participação dos indivíduos, tanto na forma quanto no conteúdo do programa.

A TV Integração, afiliada da Rede Globo, abrange toda a Zona da Mata mineira. O quadro "VC no $M^{\prime \prime}{ }^{5}$, que é transmitido na $1^{\text {a }}$ Edição do telejornal MG1, foi moldado para seus telespectadores. Nele, as pessoas podem enviar vídeos, imagens, críticas e opiniões de algo que está acontecendo na sua rua, bairro ou cidade.

5 Esse formato de quadro foi criado pela própria emissora TV Globo, tendo em outras praças também, como, por exemplo, em São Paulo, Rio de Janeiro. 
O próprio site globo.com, voltado para a região da Zona da Mata e Campo das Vertentes ${ }^{6}$, de Minas Gerais, estimula que os internautas participem através do WhatsApp, Viber ou telefone, com orientações sobre como encaminhar fotos e vídeos. Abaixo há uma orientação da equipe para os seus usuários.

\begin{abstract}
Dicas: o ideal é gravar o vídeo com o celular deitado, porque a imagem ocupa toda a tela e aparece por inteiro e na hora de enviar o vídeo ou a foto; não se esqueça de escrever também algumas informações. É muito importante acrescentar também o nome da rua e do bairro onde a imagem foi feita e alguns detalhes sobre o assunto. Se possível, enviar também o nome de quem gravou o vídeo para a equipe do MGTV dê os créditos aos telespectadores. ${ }^{7}$
\end{abstract}

Diante dessa informação veiculada pelo site, publicada em 2015, é possível observar que há uma tentativa de se manter certa interação, "já que são os produtores do programa que selecionam o material enviado pelos telespectadores e julgam, de acordo com a linha editorial do programa ou da emissora, quais merecem espaço no discurso do telejornal" (CROCOMO; CAVENAGHI; FRAZÃO, 2013, p. 12). Cada noticiário possui o seu público-alvo, então, é fundamental haver uma seleção dos conteúdos para cada telejornal e para cada espectador.

Em vista desses fundamentos, é importante ressaltar a diferença de dois conceitos abordados por Primo (2003): interatividade e interação. 0 autor menciona que a interatividade está relacionada com uma interação que é intercedida pelo computador e/ou por suas redes digitais. É uma delimitação do contexto comunicativo que está correlacionado com as novas tecnologias da comunicação, principalmente com a Internet. 0 termo interação está voltado para a relação constituída entre os interagentes e não pelos componentes do sistema global. A palavra "interatividade" deriva de "interação", um fundamento que, normalmente, significa influência mútua/troca.

Ainda conforme o autor, a interação pode ser dividida em dois grupos: interação mútua e interação reativa. A primeira pode ser definida como a relação que os participantes têm ao mesmo momento que ocorrem os eventos interativos, ou seja, ela vai se atualizando de acordo com as ações de um usuário em relação a outro (ou outros). Já a interação reativa está associada com perspectivas e automatização das trocas, sendo que podem se repetir diversas vezes em uma mesma troca. Elas se estabelecem conforme são determinadas as suas circunstâncias iniciais (estímulo-resposta obtido por, pelo menos, um dos envolvidos).

Além desses dois conceitos definidos por Primo (2003), o autor ainda conceitua multi-interação. Esse termo engloba variadas formas de interações. Em uma ocasião presencial, a interação de um indivíduo com outro pode acontecer por meio de gestos, fala, cheiro, entre outros fatores. Também pode ocorrer uma interação em um chat, pois a pessoa está dialogando com outra pessoa e, ao mesmo tempo, com a interface (software), com o teclado, com o mouse, etc. Logo, podemos observar que as duas interações podem caminhar uma ao lado da outra.

\title{
4 METOdOLOGIA: ANÁLISE DE CONTEÚDO
}

Para esta pesquisa, optou-se, como base, a metodologia de Bardin (2009), que prevê a análise em etapas. Escolheu-se esse método de verificação por acreditar-se que, por meio dele, seriam alcançados os objetivos da pesquisa com resultados satisfatórios. Além disso, foi de extrema relevância para pontuar as condições e extensões dos setores comunicacionais e os materiais enviados por telespectadores. Alguns fenômenos são importantes para este estudo, pois afetam diretamente a observação, a ação

6 Disponível em: http://g1.globo.com/minas-gerais/noticia/2015/06/publico-pode-enviar-videos-e-fotos-para-o-mgtv-pelo-whatsapp-e-viber.html. Acesso em: 14 jul. 2018.

7 Disponível em: http://g1.globo.com/minas-gerais/noticia/2015/06/publico-pode-enviar-videos-e-fotos-para-o-mgtv-pelo-whatsapp-e-viber.html. Acesso em: 14 jul. 2018. 
e a prática de Análise de Conteúdo. Essa exploração de informações se converte em um aglomerado de técnicas de inspeção das tecnologias de comunicação e de definição do conteúdo das mensagens.

Bardin (2009) formulou algumas fases de análise de conteúdo que se organizaram em três direções. "1. A pré-análise; 2. A exploração do material; e, por fim, 3. 0 tratamento dos resultados: a inferência e a interpretação" (BARDIN, 2009, p. 121). Para a análise, foi realizada uma leitura flutuante das reportagens exibidas pelo programa telejornalístico escolhido. Vale ressaltar que o enfoque deste trabalho não é investigar as narrativas em si, mas sim, a temática apresentada. A partir do conteúdo coletado, observa-se o período das transmissões (dia, mês e ano), o fato e o tipo de denúncia (flagrante de moradores) que o telejornal seleciona para divulgar ao público, de forma a buscar uma possível solução do caso frente aos órgãos responsáveis.

Como fase inicial, a equipe faz o levantamento de informações (dados) e, assim, seleciona quais temas são relevantes para serem apresentados na tela da emissora. É o momento de definir bem as estratégias, a organização e os objetivos. Tendo as pautas e produções estabelecidas adequadamente, é possível realizar um trabalho mais preciso. Podemos considerar esses recursos como a pré-análise de Bardin, porque esses procedimentos são os primeiros passos para o esquema de trabalho de um veículo de comunicação, com uma boa leitura dos materiais e das normas do telejornal.

É importante haver também apuração e cautela sobre os assuntos que os telespectadores estão encaminhando; depois, deve-se realizar um recorte, estabelecer as categorias, definir em qual bloco o quadro será exibido, ou seja, é pertinente a elaboração de um roteiro completo para ir ao ar. Como argumenta a autora, quando registra que "a análise pode efetuar-se numa amostra desde que o material a isso se preste. A amostragem diz-se rigorosa se a amostra for uma parte representativa do universo inicial" (BARDIN, 2009, p. 123). Nesse caso, podemos denominar esses procedimentos como segunda fase: exploração do material.

A terceira categoria apresentada pela autora (tratamento dos resultados - a inferência e interpretação) está voltada para além dos conteúdos exibidos, buscando uma significação para o que foi apreendido. A atração da comunicação está ligada à escolha do material recolhido do público, buscando uma referência geral com imagens significativas. 0 foco que o quadro estabelece é de propiciar uma linguagem aos informantes, além de conceituar a cultura apresentada. As referências obtidas e divulgadas pelo noticiário dão sentido à interpretação do espectador.

As três análises, mostradas mais adiante, tendem a uma direção: buscam solução para problemas. Logo, há uma caracterização que as unificam. Bardin (2009) salienta que é fundamental comparar as referências e destacar o assunto nos dados. Normalmente, o "VC no MG" apresenta imagens de situações de descasos com a comunidade, e o telejornal é como se fosse a voz dos moradores que estão insatisfeitos com tanto desinteresse dos órgãos públicos. Então, além de mostrar as situações das ruas e dos bairros com o ponto de vista da população, o(a) apresentador(a) do programa aparece no final da denúncia para contar a resposta que obteve do determinado órgão competente. No jornalismo, essa fala do comunicador ao final é conhecida como nota pé.

Diante dessas exposições, nota-se que o telejornal não privilegia somente um lado da história, mas sim, busca ouvir todos os envolvidos, já que enfoca tanto a comunidade quanto os órgãos responsáveis. A partir disso, percebemos que o direcionamento do "VC no MG" tem enfoque no conteúdo enviado pelo público, porém, antes de ser transmitido, passa por uma análise de escolha. Acreditamos que os materiais recebidos do público passam por uma triagem e que os conteúdos selecionados podem estar de acordo com a estratégia do quadro ou da equipe de produção e/ou por conta de um contexto temporal que a sociedade se encontra naquele momento. 


\section{ANÁLISE DO "VC NO MG"}

Este estudo se deu em três edições desse quadro, no mês de abril de 2018. Essa escolha ocorreu por ser um mês que apresentou distintos problemas (buracos em rua, ponte em estado precário e lote abandonado e sem manutenção). Acredita-se que, dessa forma, mostra-se que o quadro registra todas as dificuldades que o público vivencia.

O primeiro vídeo a ser analisado foi exibido em 04 de abril de 2018. Nesse dia, houve a participação de um morador do bairro Jardim Santa Isabel, em Juiz de Fora, que estava denunciando um terreno abandonado. 0 telespectador enviou a imagem com receio de doenças e de que animais entrassem em sua residência. Depois, a apresentadora informou que a produção entrou em contato com a Secretaria de Atividades Urbanas explicando a situação, e foram informados que a limpeza e manutenção são de responsabilidade do dono do terreno, que seria notificado. Além disso, o programa informou que uma equipe se dirigiria ao local para fazer a limpeza no entorno do ponto de ônibus, em frente ao terreno.

Figura 1: Morador denuncia local abandonado

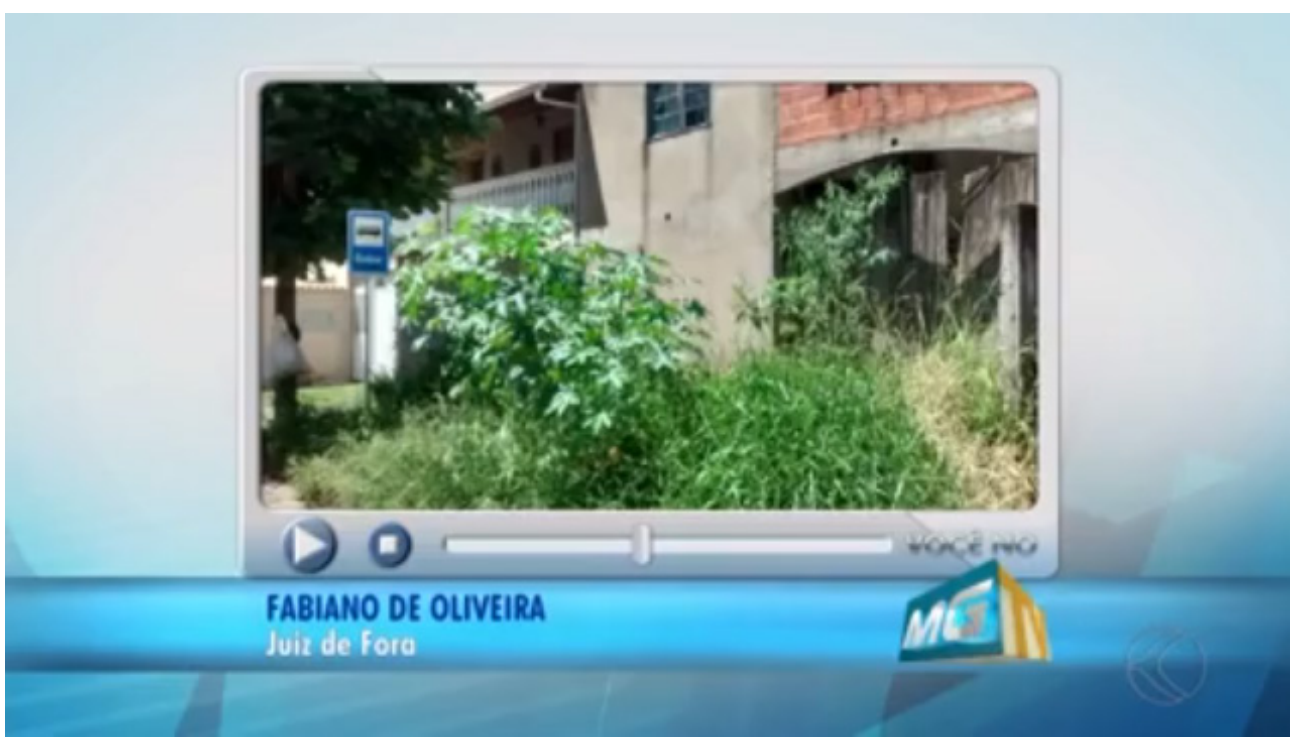

Fonte: VC no MG, 2018. Acesso em: 14 jul. 2018

Já na exibição do quadro no dia 05 de abril de 2018, moradores reclamam de buracos em uma rua do bairro Parque das Águas, em Juiz de Fora. A telespectadora conta que a rua estava com buracos, porém, após as chuvas dos últimos dias, eles aumentaram. Depois do ocorrido, a moradora ainda registra que uma mulher chegou a cair na cratera e que os ônibus não passam mais pelo local. 0 telejornal informou que entrou em contato com a Secretaria de Obras e informaram que estavam trabalhando para solucionar o problema apresentado. 
Figura 2: Imagem do espectador mostrada no telejornal

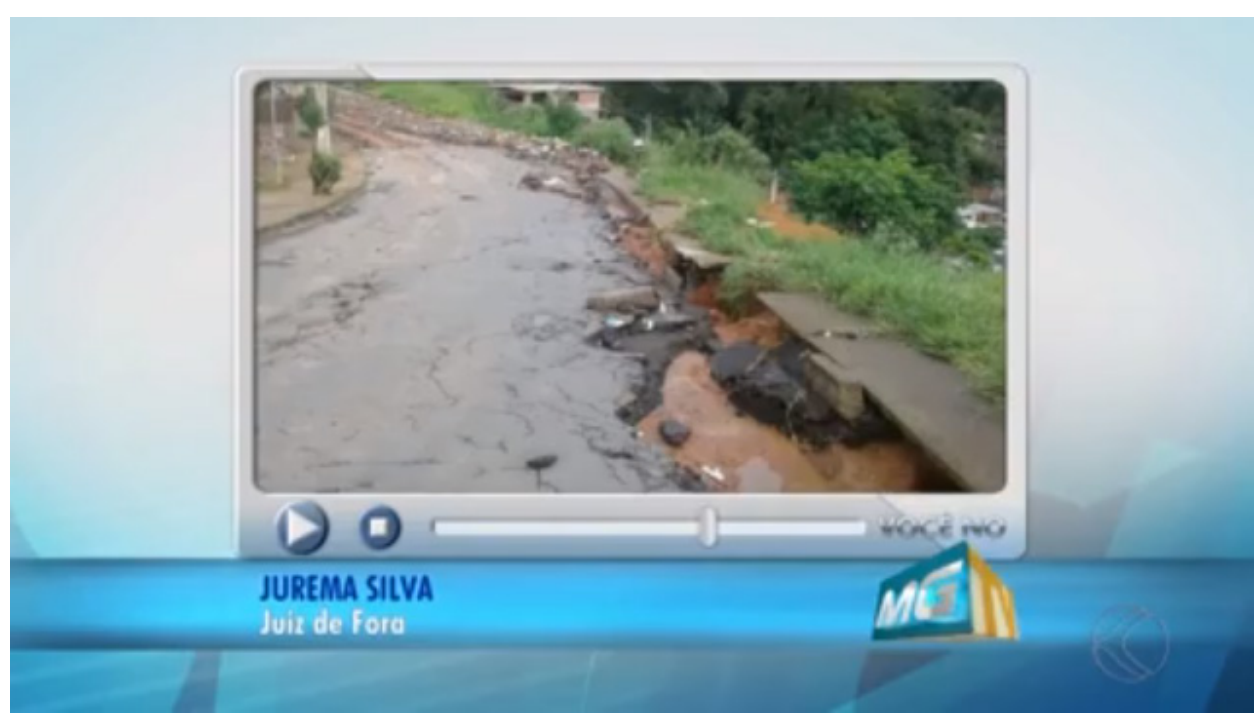

Fonte: VC no MG, 2018. Acesso em: 14 jul. 2018

Por fim, na última análise, no dia 26 de abril de 2018, moradores reclamaram da situação precária de uma ponte no bairro Diniz II, em Barbacena. 0 espectador explica que os trilhos foram retirados e havia cones e caixas atrapalhando o trânsito. A jornalista argumenta que a prefeitura da cidade informou, em nota, que os trilhos foram retirados por um morador e que o problema seria solucionado.

Figura 3: Fotografia do público apresentada no MG1

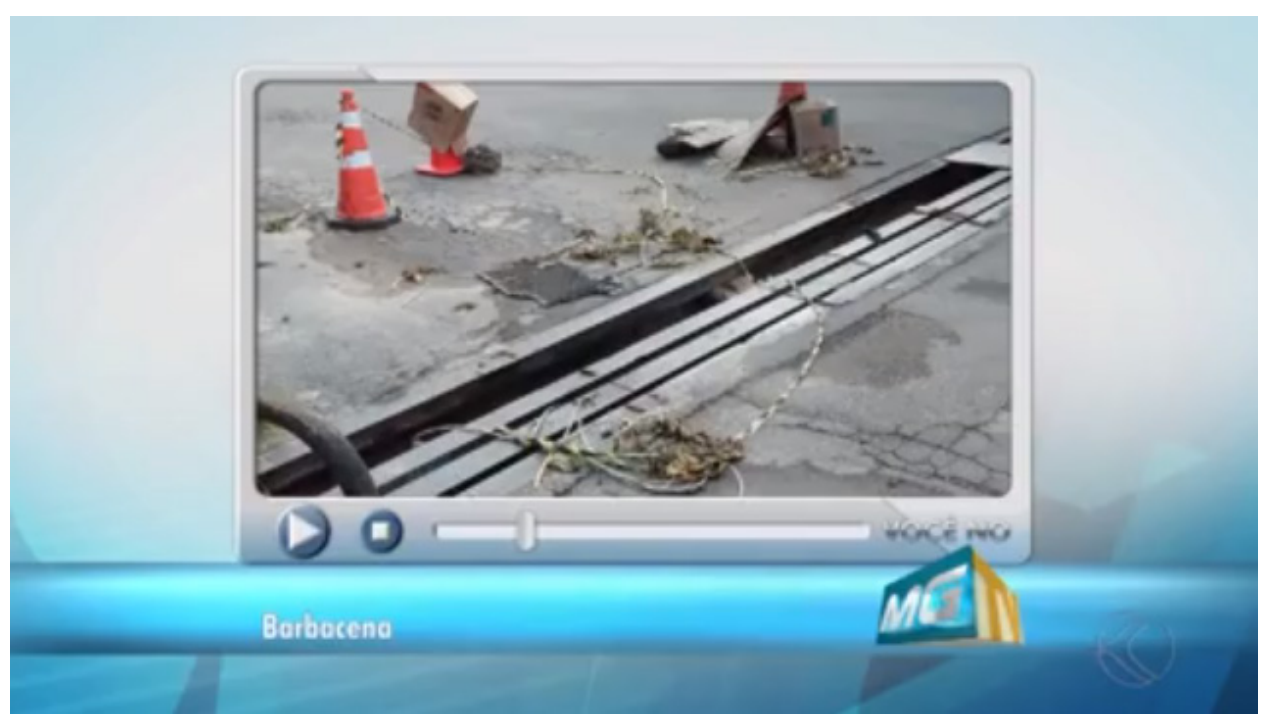

Fonte: VC no MG, 2018. Acesso em: 14 jul. 2018

Ao final de cada relato dos telespectadores, a apresentadora solicita para que as pessoas continuem enviando imagens de cenas e situações que chamaram a atenção. Logo, insere abaixo de sua fala o e-mail (mgtv.jf@tvintegracao.com.br), e depois, o número do WhatsApp (32 99925-0053) para fazer a divulgação dos fatos. Solicita, ainda, que, ao enviar as fotografias, o espectador anexe, juntamente, 0 seu nome e endereço completo de onde foi feita a imagem. Assim, notamos que os cidadãos usam os seus aparelhos digitais não somente para conversas e para registrar uma lembrança, mas também para registrar um acontecimento importante para a comunidade. 
Atentando a essas questões, observa-se a tendência do telespectador de utilizar o aparelho móvel no momento em que assiste à televisão e as experiências realizadas pelos canais, o que possibilita que a "segunda tela" auxilie para que a audiência continue conectada ao telejornal e não se distraia perante as informações disponíveis na TV e no smartphone, notebook ou tablet.

\begin{abstract}
O telespectador é, de fato, determinante na produção televisiva, já que toda produção é realizada para ser vista e para agradar a maior audiência possível, mas, quando o telejornal reforça que o programa só existe com a participação dele, pode acontecer uma desconstrução o lugar de fala socialmente instituído do jornalismo ao sugerir que seu processo de produção de fato depende da participação do telespectador e, além disso, que a partir desta parceria serão resolvidos os problemas que afligem a sociedade. (CROCOMO; CAVENAGHI; FRAZÃO, 2013, p. 13)
\end{abstract}

Vemos que o próprio telespectador está produzindo conteúdos e pautas para o telejornal, passando a constituir a sua programação, mas, como salienta Musse e Thomé (2015), é primordial verificar todo o material recebido e passar por uma triagem dentro da emissora, de maneira que esse determinado público esteja na posição de produtor de conteúdo, porém isso não exime ao jornalista o papel de profissional que apura os fatos e que fornece as notícias, mais conhecido, no campo jornalístico, como gatekeepers. Então, acreditamos que, mesmo com a inclusão do público como produtor de informações, o jornalista não perde o seu lugar no ambiente comunicacional, porque ele é o profissional que conhece as técnicas e habilidades jornalísticas.

Por fim, a forma temática dominante da emissora é a denúncia/flagrante, que podemos encaixar na editoria Cidade. Esse quadro, inserido na grade de programação do MG1, não exibe todas as "pautas" dos telespectadores, pois acreditamos que o telejornal deve receber, por dia, dezenas de envios de denúncias e flagrantes dos moradores da região. Com isso, o programa não consegue dar uma grande abrangência (vazão) para todos os relatos, logo, muitos não são sequer mencionados.

Percebemos que a estratégia da emissora de divulgar determinados fatos faz com que esses casos sejam introduzidos na memória de todos os envolvidos (telejornal, público e órgãos responsáveis). Porém, há supressões de outros fatos, já que não são divulgadas na mídia. Por conseguinte, esses acontecimentos levantam em questão a importância da lembrança apresentada (e, também, a esquecida), pois, como pontuam Musse e Thomé (2015, p. 2), "na fixação da memória, estabelecem-se inúmeras disputas simbólicas, porque o relato da memória é uma construção do presente que negocia com o contexto social em que os sujeitos estão inseridos".

\title{
6 CONSIDERAÇÕES FINAIS
}

Portanto, considera-se que a televisão, no Brasil, é fonte de notícias, distração e cultura para todos os brasileiros, como também é essencial no desempenho do papel social, conforme o acesso, aprendizado e lazer. A TV ainda tem a função de integrar, colocando-se em uma posição de comunicação e identidade. Logo, é adequado conceituá-la como um meio comunicacional de enorme abrangência e importância à sociedade, destacando-se entre os demais veículos e tem lugar assegurado no dia a dia das pessoas.

O telejornalismo se encontra desde o começo do meio eletrônico no Brasil, sendo o principal intermediário da veracidade, ocasionando contradições e reorganizações ligadas à realidade do país. Desse modo, os noticiários possuem uma grande capacidade de intervenção, levando suas análises da realidade a milhares de espectadores a um só tempo.

Com essas observações realizadas neste presente trabalho, certificamos que a participação ativa do telespectador no quadro "VC no MG" é essencial para uma maior proximidade entre espectador 
e telejornal. Além disso, vemos que, com as novas tecnologias nas "mãos" do público, a exigência de novas técnicas jornalísticas é essencial para um melhor direcionamento do telejornal.

Acredita-se que uma explicação para a forte participação do público na programação do "VC no MG" seria devido à estrutura, cada vez mais, enxuta das equipes de comunicação. Logo, a colaboração dos telespectadores também pode ser uma maneira de lidar com essa realidade atual.

A introdução do espectador na narrativa do programa acontece de forma que engrandece a sua participação e envolvimento na condução e produção do telejornal. De outro modo, o público conquista uma função de protagonismo e o relato de sua experiência pode possibilitar futuras reportagens. Assim, essas matérias recebem destaques nas categorias sugeridas por Bardin, pois há consistência de significados e sentidos nas imagens apresentadas no quadro.

Conclui-se que a emissora está promovendo uma interatividade com o seu público (de várias idades) e pode estabelecer um novo formato graças à inclusão diária do espectador na programação do canal. À vista disso, a maneira de assistir TV não é mais a mesma, pois, na atualidade, há a influência de aparelhos tecnológicos (convergência midiática). De agora em diante, a nova geração de público começa a ter voz em um cenário em constante transformação.

\section{REFERÊNCIAS BIBLIOGRÁFICAS}

BARDIN, Laurence. Análise de Conteúdo. Lisboa: Edições 70, 2009.

CÂMARA, Rosana Hoffman. Análise de conteúdo: da teoria à prática em pesquisas sociais aplicadas às organizações. Gerais, Rev. Interinst. Psicol. (online). 2013, vol. 6, n. 2, pp. 179-191.

CAMPONEZ, Carlos. Jornalismo de Proximidade. Coimbra: Minerva, 2002.

CIRNE, Lívia. Do papel ao computador: uma proposta de categorização dos efeitos de visualidades no telejornalismo. In: SBPJor - Associação Brasileira de Pesquisadores em Jornalismo. Santa Cruz do Sul, 2014.

CONTATO, Ana Carolina Felipe. 0 percurso da televisão e dos telejornais no Brasil: um mapeamento histórico. In.: SBPJor - Associação Brasileira de Pesquisadores em Jornalismo. Campo Grande, 2015.

CROCOMO, Fernando Antônio; CAVENAGHI, Beatriz; FRAZÃO, Samira Moratti. Estratégias de interatividade na produção telejornalística: o caso do Correspondente JA. In: SBPJor - Associação Brasileira de Pesquisadores em Jornalismo. Brasília, 2013.

EMERIM, Cárlida; BRASIL, Antonio. Hipersegmentação: pensando o conceito de telejornal na convergência. In: SBPJor - Associação Brasileira de Pesquisadores em Jornalismo. Brasília, 2013.

FINGER, Cristine; SOUZA, Fábio Canatta de. Um novo modo de ver TV. In: SBPJor - Associação Brasileira de Pesquisadores em Jornalismo. Curitiba, 2012.

JENKINS, Henry; GREEN, Joshua; FORD, Sam. Cultura da Conexão: criando valor e significado por meio da mídia propagável. São Paulo: Editora ALEPH, 2015. 
LIMA, Luisa Abreu e. Telejornal, texto e hipertexto: Pensando o noticiário em tempos de transição. In: SBPJor - Associação Brasileira de Pesquisadores em Jornalismo. Santa Cruz do Sul, 2014.

MATTOS, Sérgio. 0 resgate da memória e a construção da história da televisão no Brasil. In: Intercom Sociedade Brasileira de Estudos Interdisciplinares da Comunicação. Porto Alegre (Rio Grande do Sul), 2004.

MOTA, Célia Maria Ladeira. A construção simbólica da identidade nas ruas e na TV. p. 45-63 In: PORCELLO, Flávio; VIZEU, Alfredo; COUTINHO, Iluska (Organizadores). \#telejornalismo: nas ruas e nas telas. Coleção Jornalismo Audiovisual. v. 2. Florianópolis: Insular, 2013.

MUSSE, Christina Ferraz; THOMÉ, Cláudia de Albuquerque. Repórteres de telejornal: o perfil ditado pela Rede Globo em 50 anos de televisão. In: SBPJor - Associação Brasileira de Pesquisadores em Jornalismo. Campo Grande, 2015.

MUSSE, Christina Ferraz; THOMÉ, Cláudia de Albuquerque. Um milhão de amigos no RJTV: o telespectador como produtor de conteúdo pelos aplicativos WhatsApp e Viber. vol. 20, n 33. Porto Alegre: Sessões do Imaginário, 2015.

NILO, Adriana Tigre Lacerda. A contribuição das teorias críticas do "Laço Social" à "Tripla função da televisão" de Dominique Wolton para os estudos da mídia televisiva na Europa e no Brasil. In: Intercom - Sociedade Brasileira de Estudos Interdisciplinares da Comunicação. Curitiba, 2009.

PICCININ, Fabiana. Telejornal em circulação: das chegadas e partidas das mídias e suas audiências. In: SBPJor - Associação Brasileira de Pesquisadores em Jornalismo. Palhoça, 2016.

PICCININ, Fabiana; SOSTER, Demétrio de Azeredo. Da anatomia do telejornal midiatizado: metamorfoses e narrativas múltiplas. Brazilian Journalism Research, vol. 8, n. 2, p. 118-134. SBPJor, 2012.

PRIMO, Alex Fernando Teixeira. Enfoques e desfoques no estudo da interação mediada por computador. In: Intercom - Sociedade Brasileira de Estudos Interdisciplinares da Comunicação. Belo Horizonte, 2003.

SCHLAUCHER, Bárbara Garrido de Paiva. Telejornalismo, identidade e juventude: uma reflexão no contexto do atual cenário de convergência midiática. In: SBPJor - Associação Brasileira de Pesquisadores em Jornalismo. Curitiba, 2012.

SILVA, Pryscila; EMÉRITO, Matheus. As características transmídia e crossmídia do programa "Jogando em Casa" durante a primeira semana da Copa das Confederações. Revista Iniciacom, Vol. 6, n 1 . Intercom - Sociedade Brasileira de Estudos Interdisciplinares da Comunicação. São Paulo, 2014.

TV INTEGRAÇÃO. Morador do bairro Jardim Santa Isabel denuncia terreno abandonado em Juiz de Fora. Juiz de Fora: TV Integração. Disponível em: http://g1.globo.com/mg/zona-da-mata/mgtv-1edicao/ videos/t/edicoes/v/morador-do-bairro-jardim-santa-isabel-denuncia-terreno-abandonado-em-juiz-defora/6635004/. Acesso em: 14 jul. 2018.

TV INTEGRAÇÃO. Moradores reclamam de situação precária de ponte em Barbacena. Juiz de Fora: TV Integração. Disponível em: http://g1.globo.com/mg/zona-da-mata/mgtv-1edicao/videos/t/edicoes/v/ moradores-reclamam-de-situacao-precaria-de-ponte-em-barbacena/6691794/. Acesso em: 14 jul. 2018.

TV INTEGRAÇÃO. Moradores reclamam sobre buracos em rua do bairro Parque das Águas em Juiz de Fora. Juiz de Fora: TV Integração. Disponível em: http://g1.globo.com/mg/zona-da-mata/mgtv-1edicao/ 
videos/t/edicoes/v/moradores-reclamam-sobre-buracos-em-rua-do-bairro-parque-das-aguas-em-juiz-defora/6638279/. Acesso em: 14 jul. 2018.

TV INTEGRAÇÃO. Público pode enviar vídeos e fotos para o MGTV pelo WhatsApp e Viber. G1 MG, 2015/2016. Disponível em: http://g1.globo.com/minas-gerais/noticia/2015/06/publico-pode-enviarvideos-e-fotos-para-o-mgtv-pelo-whatsapp-e-viber.html. Acesso em: 14 jul. 2018.

TV INTEGRAÇÃO. Vídeos do MG1. Juiz de Fora: TV Integração. Disponível em: http://g1.globo.com/mg/ zona-da-mata/mgtv-1edicao/videos/. Acesso em: 14 jul. 2018. 